\title{
THE ANATOMY AND MORPHOLOGY OF FOUR TASMANIAN CUSHION SPECIES
}

\author{
by Neil Gibson
}

(with one table, four text-figures and one plate)

A study of the anatomy and morphology of four Tasmanian cushion plant species showed that anatomical convergence was not as well developed as the obvious morphological convergence. The lack of well-developed xeromorphic features in the Tasmanian species is not consistent with the hypothesis previously suggested that the cushion form evolved primarily as a strategy to maintain a positive water balance.

Key Words: cushion plant, anatomy, morphology, convergent evolution, Tasmania.

In BANKS, M.R. et al. (Eds), 1991 (31:iii): ASPECTS OF TASMANIAN BOTANY - A TRIBUTE TO WINIFRED CURTIS. Roy. Soc. Tasm. Hobart:231-238. https://doi.org/10.26749/rstpp.124.2.231

\section{INTRODUCTION}

Convergentevolution of plants inhabiting similarly harsh environments is a well-known phenomenon. Examples include the sclerophyll shrubs of Mediterranean regions (Specht 1979, Mooney \& Dunn 1970), the giant rosette plants of the tropical alpine regions(Hedberg \& Hedberg 1979, Smith \& Young 1987), and the cushion plants of the alpine regions of the Southem Hemisphere and the subantarctic islands (Heilbom 1925, Rauh 1939, Godiey 1978, Gibson \& Hope 1986).

There seems general consensus that these lifeforms evolve independently in different regions from different floras by parallel adaptation to adverse environmental conditions (Hedberg \& Hedberg 1979, Smith \& Young 1987), although the morphological changes by which they are achieved may be quite diverse (e.g. du Rietz 1931, Rauh 1939). The restricted number of lifeforms evolved in these environments implies that there may be only a few possible biological solutions to the physiological demands of extreme habitats(Mooney \& Dunn 1970, Halloy 1983).

A precise definitions of cushion plants is difficult, due to the variety of structural morphologies by which this form may arise (Hauri \& Schroter 1914, du Rietz 1931, Rauh 1939). In Tasmania, the term cushion (or bolster) plant has generally been taken to include any species that, growing singly, takes on a hemispherical or subhemispherical shape due to the close branching of its shoots and very short intemodes. These species tend to be quite hard and may coalesce to form extensive mats.

Four morphologically similar cushion species (from four different families) are found in the alpine and subalpine regions of Tasmania. Abrotanella forsteroides (Asteraceae) and Dracophyllum minimum
(Epacridaceae) are endemic species while Donatia novae-zelandiae (Donatiaceae) and Phyllachne colensoi (Stylidiaceae) also occur in New Zealand. The morphological convergence in the latter two species is so extreme that the occurrence of $P$. colensoi was not recognised until 1946 (Curtis 1946), despite collections having been made by L. Rodway in 1917 .

Morphological and anatomical studies on cushion plants by Hauri \& Schroter (1914), Hauri (1916) and Rauh (1939) have shown that many species are strongly xeromorphic. These and later authors have suggested that the evolution of the cushion form is primarily a strategy to maintain a positive water balance (Hedberg \& Hedberg 1979).

However, studies by Komer \& de Moraes (1979) on Silene exscapa L. (a cushion species from the European Alps) showed no evidence of water stress despite high leaf surface temperatures $\left(25^{\circ} \mathrm{C}\right)$. Similar results have been reported for scree plants from New Zealand, where surface temperatures may rise to $40-50^{\circ} \mathrm{C}$ (Fisher 1952). The availability of soil moisture and efficient transport systems appear to allow active plant growth under conditions of high to very high temperature without reliance on xeromorphic features to survive such periods.

In the Ecuadorian paramos (Heilbom 1925) and in Tasmania, cushion plants often grow in bog situations and rarely, if ever, suffer summer moisture restriction (Gibson 1988). During winter, however, high water deficits may develop if access to soil moisture is restricted by a frozen soil layer at times of high evaporative demand (Wardle 1971, 1974; Tranquillini 1979).

The aim of work reported here was to undertake detailed anatomical studies of the four Tamanian cushion species to determine (a) the degree of anatomical convergence in these species, and (b) the degree to which xeromorphic features were apparent, in order to 

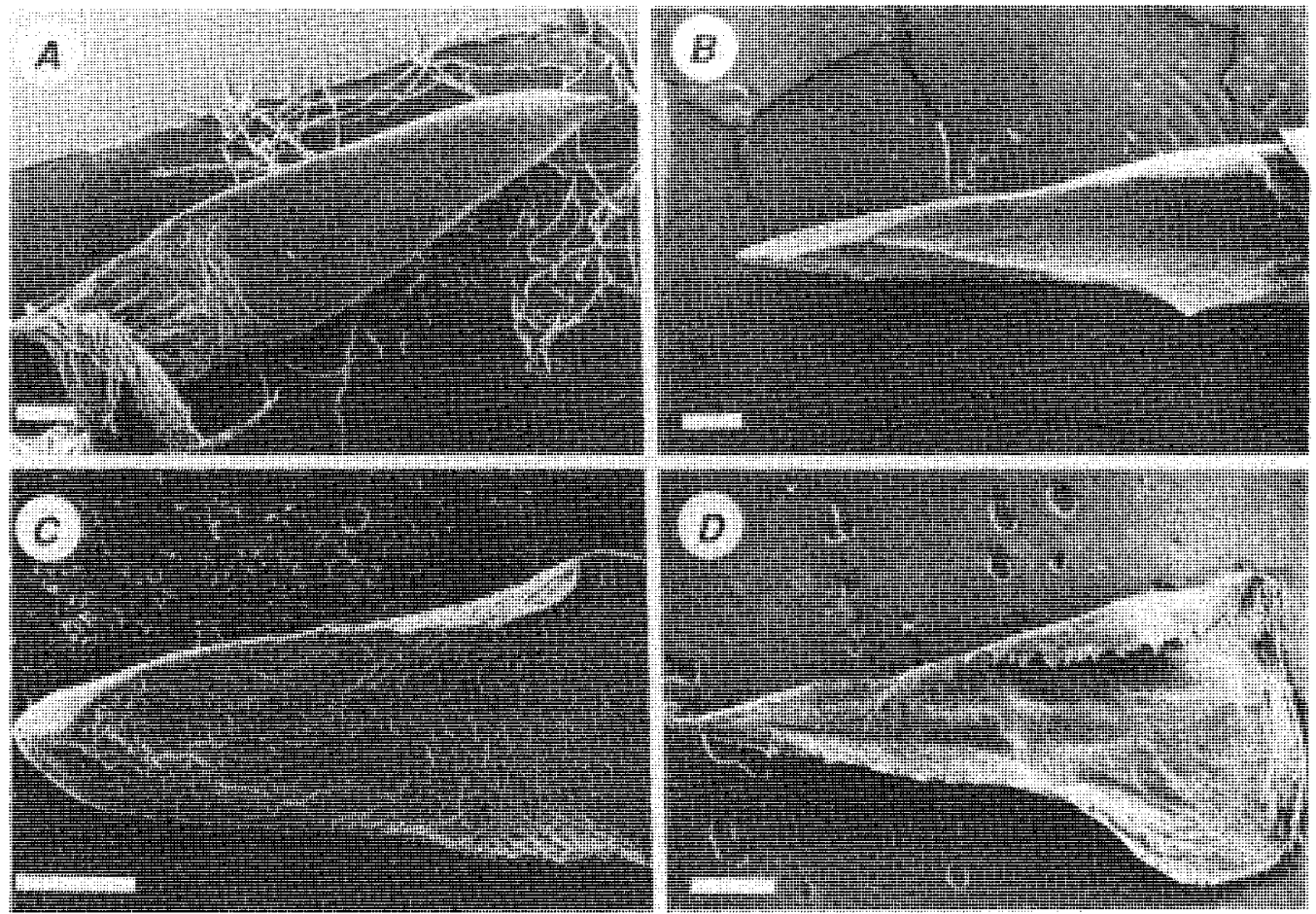

PLATE I

Scanning electron micrographs of the leaves of the four cushion species: (A) Donatia novae-zelandiae, (B) Dracophyllum minimum, (C) Phyllachne colensoi, (D) Abrotanella forsteroides. (Scale bar $=0.5 \mathrm{~mm}$.)

test the hypothesis that the water stress was a major factor in the evolution of cushion plants in Tasmania.

\section{METHODS}

Fresh and preserved material from the four cushion plant species was collected from Mt Field West and Mt Wellington. Both wax and freezing microtome sectioning were used to obtain $10-15 \mu \mathrm{m}$ transverse (TS) and longitudinal sections (LS) of the leaves and stems of the cushion plants. Sections were stained with safranin and fast green or toluidine blue. Leaf sections were obtained from a range of locations along the lamina, while stem sections were taken about $10 \mathrm{~mm}$ below the shoot apex. Anatomical diagrams were drawn using a camera lucida. Investigations of the cuticle (both scanning electron micrographs and light micrographs) of the four species have been published previously (Gibson et al. 1987: pls 2 \& 3). Nomenclature follows Buchanan et al. (1989) except where otherwise indicated.

\section{RESULTS}

Although gross morphology and structural organisation of all four species are very similar, leaf morphology and anatomy are much more variable.

\section{Donatia novae-zelandiae Hook. $\mathrm{f}$.}

\section{Leaf morphology}

Leaves are sessile $5-6 \mathrm{~mm}$ long linear-subulate with a pointed apex. The leaf base is widened and has dense tufts of white hairs $2-3 \mathrm{~mm}$ long in the leaf axis (Curtis 1963). Stomata are apparent on both surfaces with the guard cells being surrounded by a distinctive cuticular ridge (fig. 1B).

\section{Leaf surface}

Stomata are $40 \mu \mathrm{m}$ long and $30 \mu \mathrm{m}$ wide, all arranged parallel to the long axis of the leaf (pl. 1A, fig. 1B). Epidermal cells are variable in shape but have significant cell wall thickening (Gibson et al. 1987). 

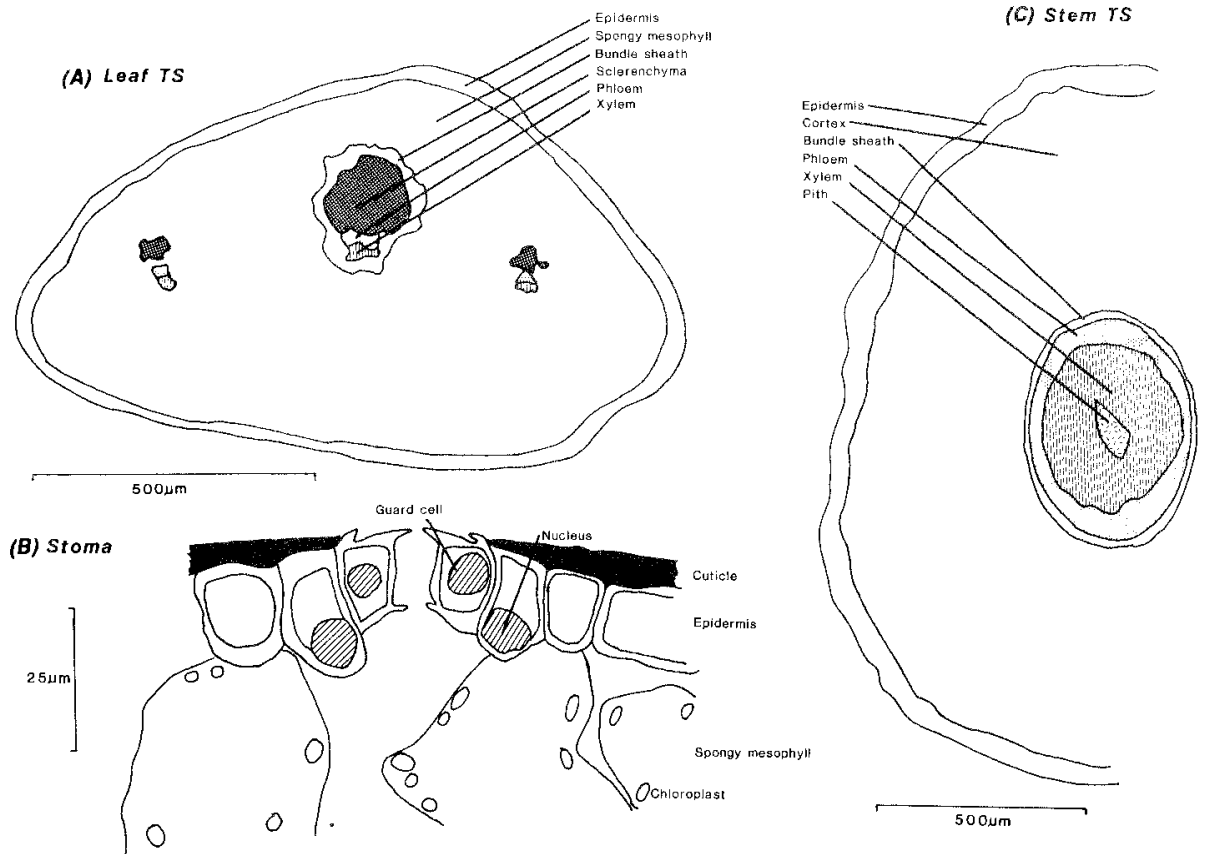

Fig. 1 - Anatomy of Donatia novae-zelandiae: (A) leaf TS, (B) stoma, (C) stem TS.

\section{Leaf TS}

A single layer of epidermal cells is covered by a thick cuticle (fig. 1A, B). No palisade mesophyll is present. Spongy mesophyll with numerous chloroplasts is traversed by three (-five) vascular bundles. The central bundle is bound by a bundle sheath and is comprised of xylem and phloem and a large cap of sclerenchyma. The minor vessels are similar, though without a bundle sheath (fig. 1A). Toward the base of the leaf up to five vessels are present. The stomata occur regularly over both leaf surfaces. The distinct cuticular ridge surrounding each stoma is formed by small outgrowths of the guard cells, which effectively limit the extent of the cuticle (fig. 1B). The guard cells also have ledges into the stomata on both upper and lower surfaces. Beneath the stomata, spongy mesophyll and large air spaces are found (fig. 1B). There are no surface trichomes.

\section{Stem TS}

The stem of D. novae-zelandiae is simple. There is an epidermis surrounding a thick cortex layer (fig. 1C), with a single vascular bundle surrounded by a bundle sheath. Stem diameter is approximately $2 \mathrm{~mm}$.

\section{Dracophyllum minimum F. Muell.}

\section{Leaf morphology}

Leaves are sessile with a broad sheathing base about as long as the blade (3-4 mm), narrow-lanceolate and slightly concave, thick and rigid. The apex is acute with leaf margins minutely serrate (Curtis 1963). The stomata are very small (pl. 1B) and occur on both surfaces.

\section{Leaf surface}

The stomata are c. $15 \mu \mathrm{m}$ in length and arranged parallel with the long axis of the leaf. The epidermal cells are much smaller than those of Donatia novaezelandiae and have highly sinuous walls. No trichomes are present (Gibson et al. 1987).

\section{Leaf TS}

A thin cuticle covers a single layer of epidermal cells. A single layer of palisade mesophyll surrounds an inner core of spongy mesophyll through which five (-nine) vascular bundles pass (fig. $2 \mathrm{~A}$ ). The main bundle is capped by a large bundle of sclerenchyma; two minor veins also have a sclereid cap while the remaining veins usually do not. Phloem in all bundles appears centrally. In the broad sheathing leaf base up to nine veins are present. The stomata occur regularly and are 


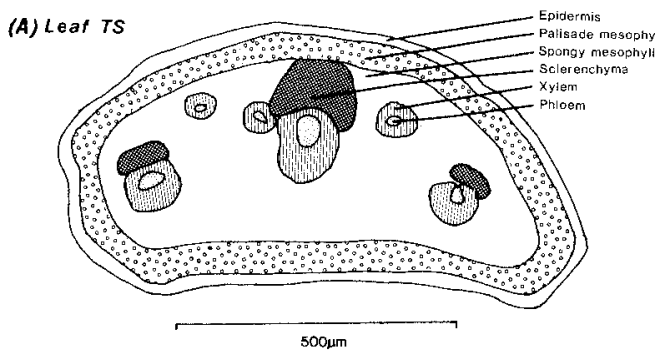

(B) Stoma' .

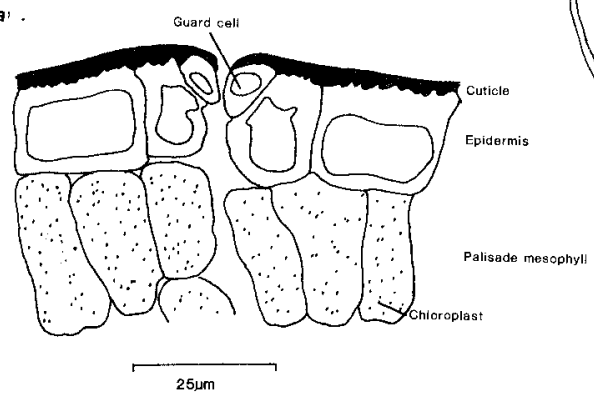

(C) Stem TS

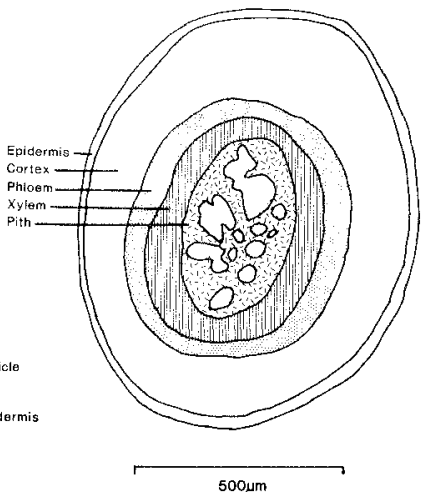

Fig. 2 - Anatomy of Dracophyllum minimum: (A) leaf TS, (B) stoma, (C) stem TS.

very slightly sunken; they consist of a pair of small guard cells, each situated above a subsidiary cell, both having a cuticular covering; they are very simple with no ledges (fig. 2B).

\section{Stem TS}

The stem of a young Dracophyllum minimum plant is very similar to Donatia novae-zelandiae except that the pith is more developed, often containing cavities. A single epidermal layer encloses a cortex and a single vascular bundle. Stem diameter is approximately $1 \mathrm{~mm}$ (fig. 2C).

\section{Phyllachne colensoi (Hook. f.) Bergg.}

\section{Leaf morphology}

Leaves sessile, 3-4 mm long, glabrous, the lower half widened and flattened, the upper half linear and thick with a glandular pore just below the apex on the adaxial side (Curtis 1963). Stomata approximately $25 \mu \mathrm{m}$ in length occur on both surfaces (pl. 1C, fig. $3 \mathrm{~B})$. The leaves are often olive-green in colour.

\section{Leaf surface}

The stomata are considerably larger than those of Dracophyllum minimum $(25 \mu \mathrm{m}$ cf. $15 \mu \mathrm{m})$. Epidermal cells are $30 \mu \mathrm{m}$ in length and have relatively thin cell walls. No trichomes are present (pl. 1C) (Gibson et al. 1987).

\section{Leaf TS}

The leaf of $P$. colensoi is very simple, being composed of a moderately thick cuticle over a single layer of epidermal cells. This surrounds a core of spongy mesophyll containing three vascular bundles, each surrounded by a bundle sheath (fig. $3 \mathrm{~A}$ ). There is no sclerenchyma in the leaf. The main vascular bundle is only slightly larger than the subsidiary veins. Stomata occur regularly over all surfaces. The guard cells are covered by a thin layer of cuticle, and raised cells have both upper and lower ledges above a substantial air space. Guard cells are surrounded by a slightly modified subsidiary cell (fig. 3B).

\section{Stem TS}

The stem of $P$. colensoi is very similar to the related Donatia novae-zelandiae, with an epidermis, an outer cortex layer and a single central vascular bundle with a central pith (fig. 3C). Although D. novae-zelandiae is placed in its own monogeneric family (Donatiaceae) by most authors, due to incomplete fusion of the style and stamens, earlier work had placed it in the Stylidiaceae (Curtis 1963). 


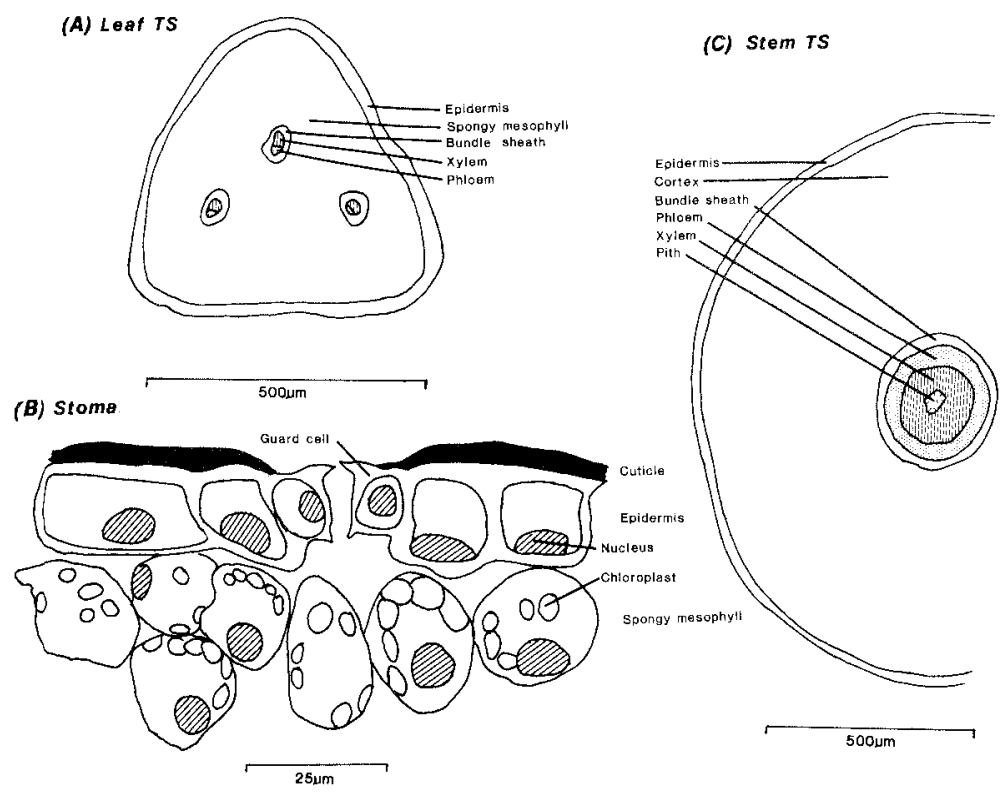

Fig. 3 - Anatomy of Phyllachne colensoi: (A) leaf TS, (B) stoma, (C) stem TS.

\section{Abrotanella forsteroides (Hook. f.) Benth.}

\section{Leaf morphology}

Leaves are sessile c. $4 \mathrm{~mm}$ long with a broad sheathing base. The leaf tip is hyaline and acuminate, the leaf margins are obscurely serrulate (Curtis 1963, Gibson $e t$ al. 1987) (pl. 1D). The hyaline leaf tip can give the otherwise green cushion a silvery appearance when a hand or finger is run across its surface. Stomata occur in bands up both surfaces.

\section{Leaf TS}

The single layer of epidermal cells is covered by a thick layer of cuticle (fig. 4B). Sunken multicellular trichomes are scattered over the leaf surface (fig. 4A,B). These structures are made of $10-15$ cells, are broadly cuneate and are attached to the leaf surface by a modified epidermal cell. The trichome tip is slightly sunken below the leaf surface and is c. $30 \mu \mathrm{m}$ in length and c. $25 \mu \mathrm{m}$ broad at the top. Within the trichome cavity, cuticle thickness becomes attenuated so that the trichomes are almost completely free of cuticle (fig. 4B).

There are two layers of palisade mesophyll on the adaxial side but only one on the abaxial side, a layer of spongy mesophyll traversed by a single vascular bundle.
The bundle is enclosed in a sheath and includes a major duct, a fibre cap, phloem and xylem tissues (fig. 4A,C).

The duct appears empty and is surrounded by a distinct layer of cells. It is c. $100 \mu \mathrm{m}$ in diameter and LS sections show it to run the full length of the leaf. Its function remains obscure. The phloem tissue is split into two discrete bundles by an intrusion of sclerenchyma in the lower half of the leaf. The stomata appear on both leaf surfaces in broad bands running parallel to the leaf axis (Gibson et al. 1987). The stomata are c. $30 \mu \mathrm{m}$ in diameter and very simple, with no ledges, ornamentation or specialised subsidiary cells. The leaf cuticle does not cover the guard cells (fig. 4D).

\section{Stem TS}

The stem is similar to the other three species except for the inclusion of three major ducts (fig. 4E). A singlelayered hypodermis beneath the epidermis encloses a cortex. The single vascular bundle is enclosed by a sheath. Immediately outside this sheath are three ducts identical in form to those found in the leaf. Stem diameter is c. $1 \mathrm{~mm}$ whilst the ducts are c. $100 \mu \mathrm{m}$ diameter. 

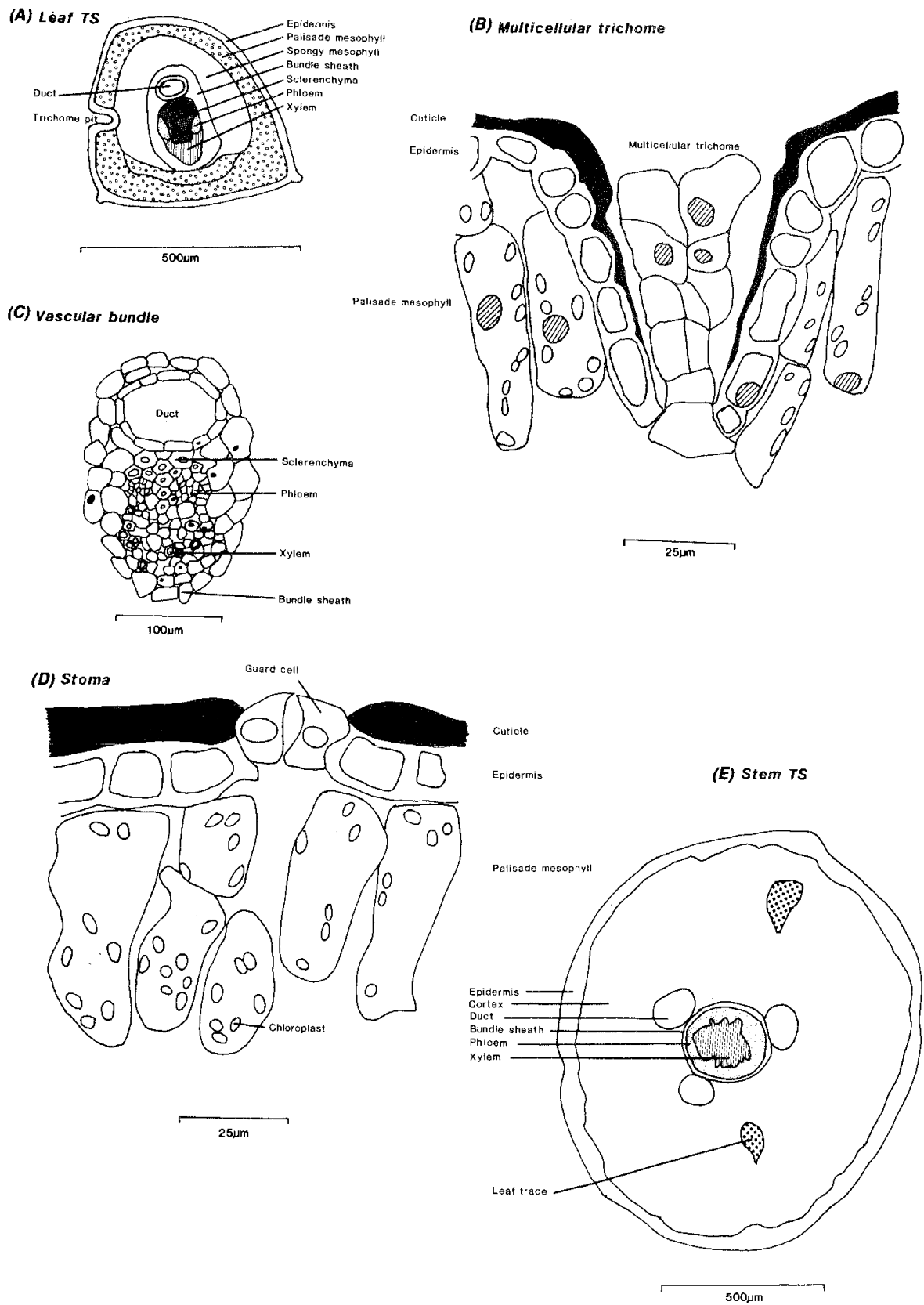

Fig. 4 - Anatomy of Abrotanella forsteroides: (A) leaf TS, (B) trichome, (C) vascular bundle, (D) stoma, (E) stem TS. 


\section{DISCUSSION}

All four species of cushion plant show a high degree of morphological convergence. All have closely compacted, highly branched stems with very short internodes. All the leaves are sessile, small and ridged with stomata on both surfaces.

The internal structure is much less uniform and consequently more difficult to compare. Of the four species Donatia novae-zelandiae and Phyllachne colensoi are the most similar, which is not surprising given the taxonomic affinity between these species (Curtis 1963). The major difference between the two is the lack of sclereids in $P$. colensoi. The internal structure and stomata are very similar (figs 1,3 ).

Dracophyllum minimum has quite distinct leaf anatomy, with a palisade mesophyll and numerous minor veins all running parallel with the axis. Its internal structure is almost identical to the closely related New Zealand cushion plant D. muscoides Hook. f., except for the absence of the second palisade layer on the adaxial surface (Hauri 1916).

Abrotanella forsteroides shows the most complex anatomy, with the presence of well-developed ducts through leaves and stem, and the presence of sunken multicellular trichomes (fig. 4B). The function of both these structures is obscure, but the ducts may be important in the aeration of plants growing in highly anaerobic peats.

It is difficult to quantify the degree of dissimilarity between the four cushion species because no comparative data are available for other lifeforms found in this environment and the functional significance of many anatomical features is poorly understood (e.g. ducts in A. forsteroides).

All species do exhibit some xeromorphic characters that are generally equated with severe water stress (Jeffrey 1987) (table 1). However, none could be considered to be particularly well adapted to cope with the severe water stress that might develop under conditions of restricted soil moisture and high ambient temperature. From these anatomical studies it appears that cushion plants would primarily cope with periods of high evaporative demand by stomatal closure, since the common features shared by the four species are a thick, cuticularised epidermis. The lack of sunken stomata and protective trichomes suggest such periods of stress are relatively brief.

Both A. forsteroides and Dracophyllum minimum have well-developed palisade layers and vascular bundles in their leaves $(3-5-7$ bundles/leaf in $D$. minimum and a large central xylem vessel in $A$. forsteroides). Considerably less well developed bundles are present in the other two species, which also lack a tightly packed palisade layer. These features are consistent with all four species having efficient water uptake mechanisms capable of dealing with periods of high temperature during summer, when an excess of soil water is available.

Beadle $(1966,1968)$ has suggested that xeromorphs are extremely resistant to mineral starvation. He argued that where phosphorus and nitrogen are limiting, excess carbohydrate from photosynthesis is converted into cell wall material (e.g. lignin in sclereids). This explanation may also apply to cushion plants. The highly acid, often waterlogged peats in which the cushion plants grow can be expected to be very low in available phosphorus and nitrogen (Swift et al. 1979).

Other studies of the comparative anatomy of cushion plants have reported a similar degree of anatomical variability (Ancibor 1971, 1980, 1981). In a study of 14 species from the cold arid puna region of Argentina (rainfall c. $300 \mathrm{~mm}$; altitudes $3400-5100 \mathrm{~m}$ a.s.l.), where high levels of water stress might be expected, it was found that most of the anatomical features could be interpreted in terms of minimising the effects of strong radiation, low temperatures and wind rather than a response to water deficits (Ancibor 1980). It appears

Table 1

Xeromorphic Characters often Associated with Adaptation to Water Stress*

\begin{tabular}{lcccc}
\hline & Donatia & Dracophyllum & Phyllachne & Abrotanella \\
\hline Microphyllous habit & + & + & + & + \\
Thick epidermis & + & + & + & + \\
Abundant sclerenchyma & + & + & + & + \\
Thick cuticle & + & + & - & + \\
Tightly packed mesophyll & - & - & - & - \\
Sunken stomata & - & - & - & - \\
Numerous protective trichomes & - & &
\end{tabular}

* After Jeffery (1987). 
that, while the particular environments may preferentially facilitate the evolution of the cushion form, the selective pressures for this may be acting at the morphological rather than the anatomical level. All four Tasmanian species show some development of xeromorphic characters. However, these are not consistent with the hypothesis that these species would undergo significant periods of winter desiccation. Rather, some features, such as reduced leaves and welldeveloped cuticle, are likely to be either genetic or phenotypic adaptation to extreme environmental parameters (e.g. ice ablation, high winds), while other features may be adaptations related to mineral starvation or waterlogged conditions. The extent to which these anatomical features are genetically fixed is unclear.

\section{REFERENCES}

ANCIBOR, E., 1971: Estudio anatomico y morfologico de una crucifera andina en cojin: Lithodraba mendocinensis. Darwiniana 16: 519-561.

ANCIBOR, E., 1980: Estudio anatomico de la vegetation de la puna de jujuy. II - Anatomia de las plantas en cojin. Bol. Soc. Arg. Bot. 19: 157-202.

ANCBOR, E., 1981: Estudio anatomico de la vegetacion de la puna de jujuy. IV - Anatomia de las plantas en roseta. Lilloa 35: 125-136.

Beadle, N.C.W., 1966: Soil phosphate and its role in moulding segments of the Australian flora and vegetation, with special reference to xeromorphy and sclerophylly. Ecol. 47: 992-1007.

Beadle, N.C.W., 1968: Some aspects of the ecology and physiology of Australian xeromorphic plants. Aust. J. Sci. 30: 348-356.

Buchanan, A.M., McGeary-Brown, A. \& Orchard, A.E., 1989: A census of the vascular plants of Tasmania. Tas. Herb. Occ. Publ. 2: 1-82

CuRTis, W.M., 1946: Phyllachne colensoi (Berggren), an addition to the list of subantarctic plants in the Tasmanian flora. Pap. Proc. Roy. Soc. Tas. 80: 3133.

CURTIS, W.M., 1963: THE STUDENT'S FLORA OF TASMANIA, PART II. Government Printer, Hobart.

DU RIETz, G.E., 1931: Life-forms of terrestrial flowering plants. Acta Phytogeogr. Suecica 3: 1-95.

FISHER, F.J.F., 1952: Observations on the vegetation of the screes in Canterbury, New Zealand.I.Ecol. 40: 156167.

Grison, N., 1988: A study of the biology of four Tasmanian cushion species. Unpubl. PhD thesis, University of Tasmania.

Gisson, N. \& Hope, G.S., 1986: On the origin and evolution of Australasian alpine cushion plants. In Barlow, B.A. (Ed.): FLORA AND FAUNA OF ALPINE AUSTRALASIA. CSIRO, Melbourne: 63-82.
Gibson, N., Kiernan, K.W. \& Macphall, M.K., 1987: A fossil bolster plant from the King River, Tasmania. Pap. Proc. Roy. Soc. Tasm. 121: 35-42.

Godley, E.J., 1978: Cushion bogs. In Troll, C. \& Lauer, W. (Eds.): GEOECOLOGICAL RELATIONS BETWEEN THE SOUTHERN TEMPERATE ZONE AND THE TROPICAL MOUNTAINS. Steiner, Weisbaden: $14 \mathrm{I}-158$.

HalLOY, S., 1983: The use of convergence and divergence in the interpretation of adaptation in high mountain biota. Evol. Theory 6: 232-255.

HaURi, H., 1916: Anatomische Untersuchungen an Polster pflanzen nebst morphologischen und okologischen Notizen. Beih. Bot. Zbl. 33: 275-293.

Hauri, H. \& SCHPoter, C., 1914: Versuch einer Ubersicht der siphonogamen Polsterpflanzen. Bot. Jahrb. Syst. Pflanzengesch. Pflanzengeogr. 50 (Suppl.).

Hedberg, I. \& Hedberg, O., 1979: Tropical-alpine life-forms of vascular plants. Oikos 33: 297-307.

Heilborn, O., 1925: Contributions to the ecology of the Ecuadorian paramos with special reference to cushion plants and osmotic pressure. Svensk. Bot. Tidks. 19: 153-170.

JEFFREY, D.W., 1987: SOIL PLANT RELATIONSHIPS. AN ECOLOGICAL APPROACH. Croom Helm, London.

Korner, C.H. \& DE Moraes, J.A., 1979: Water potential and diffusion resistance in alpine cushion plants on clear summer days. Oecol. Plant. 14: 109-120.

Mooney, H.A. \& DunN, E.L., 1970: Convergent evolution of mediterranean climate evergreen sclerophyll shrubs. Evol. 24: 292-303.

RauH, W., 1939: Uber polster formigen. Wuchs. Nova Acta Leopold. 7: 267-508.

SPECHT, R.L., 1979: Heathlands and related shrublands of the world. In Specht, R.L. (Ed): HEATHLANDS AND RELATED SHRUBLANDS. ECOSYSTEMS OF THE WORLD 9A. Elsevier Scientific Publishing Company, Amsterdam: 1-17.

Sмith, A.P. \& Young, T.P., 1987: Tropical alpine plant ecology. Ann. Rev. Ecol. Syst. 18: 137-158.

Swift, M.J., Heal, O.W. \& Anderson, J.M. 1979: DECOMPOSITION IN TERRESTRIAL ECOSYSTEMS. Blackwell, London.

Tranquillini, W., 1979: PHYSIOLOGICAL ECOLOGY OF ALPINE TIMBERLINES. Springer-Verlag, Berlin.

WARDLE, P., 1971: An explanation of alpine timberlines. N.Z. J. Bot. 9: 371-402.

WARdLE, P., 1974: Alpine timberlines. In Ives,J.D. \& Barry, R.G. (Eds); ARCTIC AND ALPINE ENVIRONMENTS. Methuen, London: 371-402.

(accepted 10 August 1990)

N. Gibson

Wildlife Research Centre, Dept of Conservation and Land Management, PO Box 51, Wanneroo, WA, Australia 6065; formerly Department of Geography, University of Tasmania 